the same time provides standing place for cooking utensils on the top of the oven. The arrangements are such that the pupils can be conveniently divided into four groups. Each group is self-contained and has charge of a cooker with oven, table and washing-up arrangements, and a cupboard for utensils and crockery. The items of equipment are arranged as close together as possible and in the order in which they are required. In order to teach economy, the pupils are required to reckon up the total cost in materials and electrical consumption of all food prepared. A separate meter is usually installed in the circuit supplying each cooker. Although rarely used in schools, descriptions are given of the tilting cauldron and the tilting oven often used in hotels and institutions. The cauldrons, instead of having a tap for withdrawing the contents, are arranged to tilt and pour out the contents over a wide lip. They are mounted on trunnions and worked by a worm gear so that the tipping is done gradually without the risk of spilling. They can be kept clean as easily as a basin, and the heat control is such that even milk cannot boil over.

\section{Agricultural and Horticultural Pests}

MucH recent research into the incidence and overwintering of the potato blight fungus (Phytophthora infestans) has made it necessary for the Ministry of Agriculture to revise its leaflet upon this subject. The new Advisory Leaflet, No. 271, shows that the fungus overwinters upon infected tubers, and there are usually sufficient of these left from previous crops, or thrown out from storage pits, to begin fresh infection in the spring. Control by spraying and dusting is described, and other methods include the removal and destruction of haulm before digging the crop, and the disposal of blighted tubers. Advisory Leaflet No. 273 replaces leaflet No. 195, and deals with American gooseberry mildew (Sphorotheca mors-uvi). The subject-matter has been brought up to date. A short Advisory Leaflet (No. 182) deals with spurrey (Spergula arvensis) as an agricultural weed. Spraying with 5 per cent solution of copper sulphate, or 7-10 per cent sulphuric acid, are recommended for control of the weed amongst cereal crups, in addition to the application of lime, and other methods.

\section{Medallions of Manganese Steel}

When King Edward, as Prince of Wales, visited the Hecla Works of Hadfields, Ltd., some years ago, he cast a medallion portrait of himself in manganese steel. A similar medallion, 20 inches in diameter, was recently cast showing the head and shoulders of General the Right Hon. J. C. Smuts, P.C., and both are now on view at the Johannesburg Empire Exhibition, of which General Smuts is honorary president. The manganese steel of which these medallions are made is run juto the moulds at a temperature of about $1,450^{\circ} \mathrm{C}$., but despite this high temperature, and owing to the speciallv developed moulding sand employed, the definition of the features is remarkable, each detail being reproduced as clearly as in a photograph.

\section{Faraday House Journal}

WITH the opening of the Michaelmas term at Faraday House Electrical Engineering College, Faraday House Journal makes its reappearance and, in addition to the usual personal, social and collegiate items, the present number contains several short papers of note. The principal, Dr. A. Russell, writing under the title "Unfettered Mathematies in Engineering", continues his articles on capacitance coefficients, and here shows that the capacitance of a system of two external spheres can be expressed in terms of certain spherical condensers, the values of which can readily- be found. In a paper "On a Natural System of Absolute Physical Measurement", Sir Ambrose Fleming puts the case for, and gives data relative to, a system based on the rest mass of the nucleus of the hydrogen atom and the wave-lengths and periodic times of certain of its radiations. "Fluorescence under Ultra-Violet Light" by Dr. W. R. C. Coode-Adams and "Perspective" by the Rev. L. Van Vestraut complete this section of the contents and their titles sufficiently indicate the nature of these two papers.

\section{Bureau international des Poids et Mesures}

Dr. Charles-Edouard Guillaume, director of the Bureau international des Poids et Mesures, is retiring after fifty-three years in the service of metrology. The permanent administrative committee of the International Committee of Weights and Measures, which consists of Prof. V. Volterra of Rome (president), Prof. B. Cabrera of Madrid (secretary), Prof. P. Janet of Paris, Prof. P. Zeeman of Amsterdam, and Dr. C. E. Guillaume, has nominated M. Albert Perard, assistant-director of the Bureau, to succeed Dr. Guillaume. M. Pérard, like his predecessor, has spent all his life at the Bureau; he is best known for his work on the metrology of the interference of light. The Bureau, the oldest of the international scientific organizations, is at the Pavillon de Breteuil, Sèvres, Seine-et-Oise; since the signature of the Convention of the Metre in 1875, it has been under the direction in turn of G. Govi, O. J. Broch, J. R. Benort and Dr. Guillaume.

\section{New Midwives' Service}

A crrcular on the Midwives Act, which has recently become law, has been issued by the Minister of Health (Circular 1569. London: H.M. Stationery Office. 6d. net). The Act marks an important advance in the policy of improving the public health services of Great Britain, and should do much to improve the maternity services, and secure a reduction in the present rate of maternal mortality. The Act aims at providing every prospective mother whose baby will be borne at home with the services of a trained midwife for her confinement and fourteen days thereafter. The new arrangements should also do much to improve the status and prospects of midwives who enter the new service. The Circular, which is addressed to the local authorities administering the Act, contains a memorandum fully explaining the provisions of the Act. 